\title{
A comparative look at the teacher training systems: Belgium - Flemish Community and Turkey
}

\author{
Gülçin Mutlu'
}

\begin{abstract}
This study aims to have a comparative look at the two countries, Belgium - Flemish Community and Turkey with regard to teacher training systems and qualitatively investigate the differences between these countries. The comparison themes for which these comparative analyses were based on were derived following a determination of the most prominent aspects of teacher education terminology. These themes include such education and teacher education related concepts as a) teacher education curriculum components, b) teacher employment, c) teacher career steps, d) in-service training, e) status of teachers and f) teacher evaluation. Comparative results were presented by means of the data gathered with regard to the above themes. The analyses indicated several differences between the teacher training systems of the two countries especially in relation to evaluation and accreditation of the teacher training programs, continuing professional development options, teacher evaluation methods and functioning of the teacher unions. Thus, in the light of the results of this study, several recommendations were put forth about the potential problem areas in our local context, that is, Turkey and what could be done to overcome those in the field of education as a candidate state of the European Union.
\end{abstract}

Keywords: Comparative Education; Teacher Education; Comparative Teacher Education; Flemish Teacher Education System; Turkish Teacher Education System.

\section{Introduction}

In the global world, it has always been a common strategy to watch and follow the practices and implementations of other countries in most legal and social issues. In this vein, education is also one of this core issues and the countries have been comparing and contrasting their educational practices with those in the other countries in order to develop and renew theirs. Hence, this study aimed to compare and contrast Flemish and Turkish teacher education systems so as to bring about some productive conclusions to develop the Turkish education system in that Flemish education system is credit with its developed education system as a strong member of European Union. The following starts with the presentation of general information about Flanders and Flemish education system and then presents the methods used in the analysis and finally the comparative results based on the teacher training-related educational themes derived.

\section{General Overview of Flanders}

Belgium has a dual federal structure, and Flanders composes one of the federated states of this dual entity. Flanders is situated in the northern part of Belgium which contains that contains the cities of Brussels, Bruges, Ghent and Antwerp and it has a population of slightly over six 
Mutlu, G. (2016). A comparative look at the teacher training systems: Belgium - Flemish Community and Turkey. Journal of Human Sciences, 13(2), 3320-3337. doi:10.14687/ihs.v13i2.3809

million. The official language is Dutch. Brussels is the capital city of Flanders, and it is also the capital of Belgium and of Europe (Flemish Ministry of Education, 2008; U. S. Department of State, 2012).

The federal state structure of Belgium encompasses three policy levels, federal state, regions and communities with each having its own legislative and executive bodies (UNESCO, 2007). The federal state includes the whole area of Belgium and the whole population, while regions and communities stand for relevant entities. There are three regions which are the Flemish Region (Flanders), the Walloon Region and the Brussels Capital Region. There are three Communities formed on a language basis that are the Flemish Community (including the inhabitants of the Flemish Region and the Dutch speaking inhabitants of Brussels), the French Community (including the Walloon Region and the French-speaking inhabitants of Brussels) and a German-speaking Community (including the inhabitants of the German-speaking area). Flanders in fact includes both the Flemish Community and the Flemish Region, that is, the Flemish Community and the Flemish Region form one single parliament and one single government. Such a differentiation lies in the sharing of the regional and communal powers. The Flemish Region deals with such territorial issues as agriculture, environment and energy, while the Flemish community deals with social issues, such as education, health and culture (Flemish Ministry of Education, 2008; OECD, 2002). For the purpose of this paper, only education in Flanders (i.e. the education system of the Flemish community as the educational powers lie within the communities) will be discussed.

Educational Policy and Governance

Flemish educational policy is accredited with a complex interplay between the ministry of education, the educational networks and the local schools. The educational networks called community education, subsidized public-authority education and subsidized private-authority education are the umbrella bodies for above the local bodies of schools. Though all educational powers are exerted by the communities and their ministries of education, federal state still holds some responsibilities such as the ages for compulsory education, diploma qualification requirements and pensions. The federal state provide financial contribution for educational matters to the communities, but the Flemish government has some other sources such taxes and regional income that will also contribute to the education sector in the Flemish community. In the decentralized Flemish education system, governing bodies and school boards have the autonomy in the recruitment of the teachers, choice of teaching materials and methodologies and designing their own curricula based on the core competencies and objectives determined by the Flemish community. There are also educational umbrella organizations (see Appendix A for these organizations) that various groups of organizing bodies come together and establish to provide support for the education system (Eurydice, 2011).

\section{Quality Assurance and Evaluation of Education}

Education inspectorate is responsible for monitoring the quality of education in all schools, that is, the institutions of elementary and secondary education, adult secondary and basic education, part-time arts education and the centers for pupil guidance. The education inspectorate performs evaluations in teams through systematic differentiated school system. By taking the school profile into consideration, the education inspectorate identifies an assessment focus area for each school and prepares reports on the strengths and weaknesses of the schools, and their results are published on the website of the education inspectorate. Educational inspectorate is not in charge of evaluations conducted at the higher education level (Eurydice, 2011).

\section{A Snapshot of the Education System of Belgium Flemish Community}

The Flemish education system encompasses elementary education (including pre-primary and primary education), secondary education (including mainly three stages) and bigher education (including universities and university colleges; see Figure 1; another table is provided in Appendix B). 
Mutlu, G. (2016). A comparative look at the teacher training systems: Belgium - Flemish Community and Turkey. Journal of Human Sciences, 13(2), 3320-3337. doi:10.14687/jhs.v13i2.3809

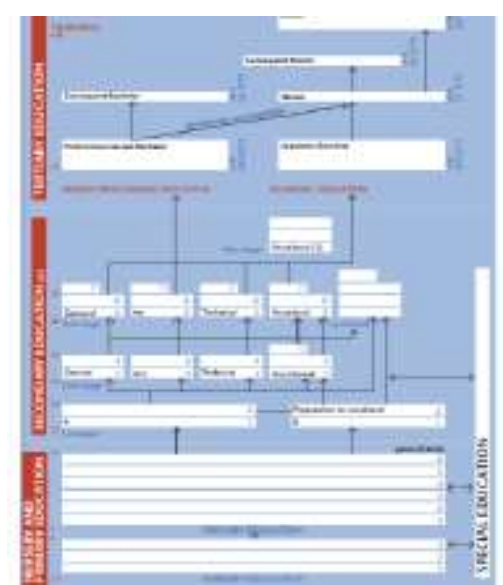

Figure 1. Structure of the Flemish Community education system (*from UNESCO, 2007)

Compulsory education lasts for 12 years, from the month of September a child turns into six years of age until the end of the June of the year she or he becomes 18 years old. Compulsory education is full-time until the age of 15 or 16. From that time, part-time compulsory education could be offered. In Flanders, compulsory education could also be achieved through home schooling (which satisfies the legally imposed requirements), that is, school attendance is not the only mean to complete compulsory education. Compulsory education is free of charge in Flanders. There is no national test of learning outcomes at this level at any level of the education system in Flanders.

Elementary education encompasses pre-primary (nursery) and primary education. Preprimary education is offered to children aged from two and half years old to six years old, and it is voluntary and free of charge. Three age groupings (from two and half to four; from four to five and from five to six year-olds) are used for organizing the classes in pre-primary education. Primary education comprises six years of study (from 6 years to 12 years). It is again free of charge. Secondary education is includes six years of study divided into three two- year stages. In other words, there are three stages, and each stage has two grades. In the first stage of the secondary education (Stage I), there are two streams called first year A and first year B. First year B is offered for those who have fallen behind in their education. Completing the first year B stream, students may proceed to the second grade (called pre-vocational year) or to first year A (by taking one extra year). The students completing Stage I can progress to Stage II which has four options for further study, general, technical, artistic and vocational. There is an alternatively study track for students at that point. After the Stage I of the secondary education, students may choose between four full time tracks (options above) or three part-time tracks. The next stage, Stage III offers a supplementary study to the Stage II in that it becomes a preparatory study for higher education for artistic and general education tracks, or a specialization study for vocational and technical secondary education tracks. In talking about the part-time secondary education options (that provides a combination of learning and practical training), they include part-time secondary vocational education offered by part-time secondary schools, apprenticeship offered by Syntra training centers (Syntra stands for Flemish Agency for Entrepreneurial Training) and other part-time training programs (EuroEducation, 2016; Eurypedia, 2012; Flemish Ministry of Education, 2008; OECD, 2010; UNESCO, 2007).

Students completing secondary education are eligible for applications to the higher education offered by professionally-oriented colleges of higher education or universities, and there is no specific criteria or exam (apart from medicine and dental faculties) to apply. Students pay a fee for higher education. 
Adult education in Flanders is offered by Centers for Adult Education which organize programs for adults at the secondary education level, higher vocational programs, basic programs to contribute to level of literacy and some teacher training programs. In addition to mainstream elementary and secondary education, there is also special education corresponding to the same levels of the mainstream education. Special education may also be offered in an integrated manner with the mainstream education in that students with special needs and problems attend classes and activities at mainstream schools with the support from special education (Eurypedia, 2012).

\section{Purpose}

This study aims to compare the teacher training systems with the help of several documents and academic sources. Thus, this study is a qualitative inquiry of similarities and differences between the two teacher training systems with regard to a number of characteristics. The following research question guided this inquiry:

(1) How does Turkish teacher education system differ from the Flemish teacher education system in relation to the following educational characteristics?:
a. structure of teacher education systems
b. types of teachers working at different levels and schools types
c. admission requirements to the teacher training programs
d. curriculum and level of specialization in teacher training
e. admission to teaching positions and entry to the profession
f. teachers' legal status and image in the public
g. conditions of service and salaries of teachers
h. continuing professional development
i. stages in the teaching career and career ladders
j. supporting measures for teachers and teacher education
k. evaluation and accreditation of teacher training programs
1. evaluation of teachers
m. positions of academic staff

\section{Method}

This study aims to qualitatively compare the Turkish and Flemish educations systems with regard to a number of characteristics peculiar to teacher education systems. Thus, the researcher first developed themes that would serve as criteria upon which the comparison of the teacher education systems of the two countries would be based. Hence, several themes were derived following a detailed review of the literature. These themes include such teacher education related concepts as teacher education curriculum components, teacher employment, teacher career steps, in-service training and teacher evaluation. With the help of the data collected in relation to above themes, some comparative analyses were performed. Following such analyses, the results were presented in relation to these themes.

\section{Comparative Results}

\section{Results regarding Teacher Education Systems}

All teachers in general education levels in Flanders, that is, in pre-primary, primary or secondary education or in part-time arts education are required to successfully complete a teacher training course (program). Since 2007 (following the Decree 15 December 2006), two versions of initial teacher education have been in practice to train teachers for the nursery and other school 
education levels, and also in part-time arts education and adult education levels. The following summarizes the two types of initial teacher training programs in Flanders:

Integrated teacher training program is the type of teacher training program which is only offered at university colleges (hogescholen in Dutch), and it integrates subject content and pedagogical studies. Integrated teacher training leads to a Bachelor degree in education, more specifically in preprimary (nursery) education, primary and secondary education (Eurypedia, 2012; Eurydice, 2011).

Specific teacher training program is the other type of teacher training program taken after or as part of a subject-specific initial program, and it is offered at a university college (for graduated Bachelors), at a university (for graduated Masters) or at a Centre for Adult education (for graduated Bachelors and Masters). Specific teacher training is also taken following one's professional experience in that it may be offered to those professionals in the arts (e.g. artists, musicians and actors). In this regard, this type of teacher training program encompasses exclusively pedagogical studies as the participant teacher trainees already possess a degree (i.e. another diploma in higher education or adult education) and perhaps professional experience in their subjects. In looking at the above account and relating it to the existent teacher training models in the Flemish system, one can easily understand that there is either concurrent (i.e. with pedagogical training taken together with the Bachelor's program as in the integrated teacher training program above) or consecutive model (with the pedagogical training taken after the initial degree as in the specific teacher training programs taken after the initial subject-specific degree) in practice in Flanders (Eurypedia, 2012; Comace, 2012). It is important to note that both types of training lead to the same qualification, the teacher's diploma. As is also understood from the above account, university colleges, universities and centers for adult education are responsible for teacher education for teachers in general education. However, in talking about the Bachelor degree teacher education programs, the only responsible body is the university colleges, the colleges of education (hogescholen) affiliated to the universities. Flemish teacher education system offers no alternative training pathways to the above two teacher training possibilities. However, it appears that specific teacher training program might be thought as an alternative training pathway to the integrated initial teacher training program.

Like in Flanders, all teachers in general education levels in Turkey, that is, in elementary and secondary education are required to successfully complete a teacher training course (program) leading to a Bachelor's degree. Similar to the Flemish case, there are two ways to get this teacher training course, but there is only one body of institution responsible from teacher training (since 1982), that is, universities (i.e. education faculties within universities) as opposed to the existence of some alternatives (university colleges, universities and centers for adult education) in the Flemish system. Both Turkish and Flemish systems perform concurrent and consecutive model of teacher training. In Turkey, concurrent model of teacher education is performed by the faculties of education in that general culture courses, subject-area courses and pedagogic studies are integrated in the education faculties' curricula. For consecutive model of teacher training, non-thesis master programs are offered for those who have completed other faculties (Bachelor degree programs), primarily the bachelor degree programs of the faculties of Arts and Sciences.

\section{Results regarding Types of Teachers Working at Different Levels and Schools Types}

In looking at the education system in Flanders, there appears to be four types of teachers, pre-primary teachers (i.e. nursery teachers), primary school teachers, secondary teachers (Eurypedia, 2012). Though secondary education has four main tracks two of which (Vocational and technical secondary education) is related to vocational education and training in a broader global terminology, there appear no well-defined standards for being a vocational teacher at the secondary level, and there is no much detail about the criteria to be appointed as a vocational education teacher in the Flemish education system. Regulations on the characteristics of teachers at the arts in upper secondary and upper vocational education are not laid down (Eurydice, 2009, as cited in Comace, 2012). 'Community of knowledge on Arts and Cultural Education in Europe' (ComACE) 
Mutlu, G. (2016). A comparative look at the teacher training systems: Belgium - Flemish Community and Turkey. Journal of Human Sciences, 13(2), 3320-3337. doi:10.14687/ihs.v13i2.3809

web-based portal contends that as there is no subject-related content in arts and cultural education, there is no specific teacher who is directly responsible and called as vocational teachers.

In looking at the categorizations of teachers in the Turkish system, the categorizations of teachers are wider in that there are more groups of teachers: pre-primary teachers (holding a Bachelor's diploma of four years), secondary education teachers of specific subjects (e.g. history, geography, physics teachers; holding non-thesis master's diploma of five years), teachers in charge of both of the levels above (teachers of music, art, foreign language, physical training holding a Bachelor's diploma of four years), vocational and technical education teachers (holding a Bachelor's diploma of four years; MEB, 2011; Eurydice, 2011). In the Turkish education system there are those teachers specifically called vocational education teachers, while all those teachers in the arts and vocational subjects are included in the terminology of secondary education teachers in the Flemish system. This difference perhaps depends on the existence of separate vocational and technical high schools in the Turkish system as opposed to the Flemish system which incorporates vocational training in the second and third cycles of the secondary education.

\section{Results regarding Admission Requirements to the Teacher Training Programs}

The admission requirements to the integrated teacher training programs are the same with the other Bachelor degree programs offered by university colleges (Eurypedia, 2012). The requirements basically include a Flemish diploma of secondary education (a foreign diploma could be also recognized based on legislative procedures). Specific teacher training programs organized by the university colleges admit such students as in the following (Eurypedia, 2012):

- those having a Bachelor's degree.

- students of a Bachelor degree program who have already completed 120 credits in their degree.

- holders of Master's degrees in Commercial and Management Sciences", "Media and Visual Arts" and "Music and Performance Arts".

- those having a professional Bachelor's degree that have registered for a bridging program of Master's degree in the above three areas.

- those having a Bachelor's degree in the above three areas only when they are registered for a Master's degree program.

For the admission to specific teacher training programs offered by the universities, the following type of students may be admitted (Eurypedia, 2012):

- those having a Master's degree

- students registered to a Master's program of 120 credit (30 credits of this is given to the teacher training specialization)

- those having a Bachelor's degree on condition that they have enrolled for a Master's degree

- those having a professional Bachelor's degree that also have registered for a bridging program of a Master's degree

There are also specific teacher training programs in the Religious Studies and Theology organized by the Evangelical Faculty (Heverlee) and Faculty of Protestant Theology (Brussels), and these accept students based on the same requirements as universities.

The admission to the teacher training programs offered at the education faculties in the Turkish education system are the same with the other Bachelor degree programs offered by universities with the main requirement being success at the university entrance exam. This exam score plus a secondary education diploma requirement is different from the requirements of the Flemish system asking for only a secondary education certificate (there is no exam for the Flemish students to enter into higher education). The university entrance exam is performed and controlled by the Student selection and Placement Centre (OSYM); however, in such teacher education 
departments as music, art, physical education, students are also asked to take aptitude tests in addition to the university entrance examination. The faculties have the freedom to organize their own aptitude tests, which perhaps makes them in the sense of autonomy closer to the Flemish teacher training institutions that have the freedom to accept their students directly, and for some subject areas requiring aptitudes, the Flemish school governing bodies may as well ask the students to take similar tests.

Though the non-thesis master opportunity is a consecutive model of training that is also present in the Flemish system, with regard to admission terms, it is not offered to a wide range of other departments (like media, business administration, communication etc.) in the Turkish system as it is in the Flemish version (i.e. in the Turkish system, it is offered only to those graduates of the faculties of Arts and Sciences). Specific teacher training programs in the religious studies are included in the faculties of theology (Illahiyat Fakülteleri in Turkish) in the Turkish system with the change in 2014. Before this change, education faculties possessed religious culture and ethics teacher education departments. Likewise, in the Flemish system, teacher training in the religious studies are connected to the faculties of religious thinking and theology which may be likened to the faculties of theology in the Turkish system.

\section{Results regarding Curriculum and Level of Specialization in Teacher Training}

Teacher qualifications for general and vocational institutions are the same since 2007 Reform on Teacher Education, that is, the teachers at all levels and types of educational institutions are to possess a teacher's diploma received at the end of either integrated or specific teachertraining program options. In talking about the initial training of teachers for different types and levels of school education, the integrated teacher training programs at the university colleges provide training for all levels, nursery, primary and secondary education over a same time period of training (i.e. three years).

The courses in the teacher training programs are based upon the core competencies determined by the Flemish Government Decree of October 2007. The teacher training institutions have the freedom to develop their own curricula based upon these set core competencies. As for the curricula of integrated teacher training programs, they integrate subject studies and pedagogical and teaching components throughout the entire three-year training program. Those trained to be secondary education level teachers are required to choose two teaching subjects. The whole teacher training program encompasses 180 credits with one credit corresponding to a study load of 25 to 30 hours, and the whole academic year involves a total of 60 credits. Out of a total of 180 credits of the whole teacher education program, 45 are allocated to teaching practice. The university colleges organize the practical component in the form of a pre-service training working in cooperation with schools, centers or institutions.

In talking about the curriculum of specific teacher training programs, this training program comprises a 60-credit study load, and 30 credits of this study load are allocated to teaching practice (Eurypedia, 2012; Eurydice, 2011). The practical component of their curricula can be achieved via pre-service or in-service training possibilities. For pre-service training, student teachers perform teaching practice in schools, center or institutions with having no employment relationships with them. Teaching experience supervisor in the teacher training program and the staff member in the supportive practice school corroborate for the pre-service training of the teacher trainee. For inservice training possibility (LIO position), a Trainee Teacher (Leraar-in-Opleiding in Dutch language- shortened as LIO) work as a temporary teacher being responsible for at least 500 teaching assignment and earns a salary at the level of a teacher without a teaching certificate. The trainee teacher is mentored and supported by a staff member of the school or institution she or he works at. The teacher training college or university also assists the trainee teacher during his inservice practice (Eurydice, 2009; Eurypedia, 2012). For both specific and integrated programs, tutors who are experienced teachers might be also appointed to support trainee teachers, induction 
Mutlu, G. (2016). A comparative look at the teacher training systems: Belgium - Flemish Community and Turkey. Journal of Human Sciences, 13(2), 3320-3337. doi:10.14687/jhs.v13i2.3809

teachers (LIOs) and beginning (newly qualified) teachers (Flemish Ministry of Education and Training, 2008)

The teacher training intuitions in the Turkish system, that is, the faculties of education are responsible for the initial training of teachers for different types and levels of school education; however, the periods of training to get the diploma changes according to the subject matter studied ranging from four to five years of training, which is longer than the three-year study common to all subject areas offered at the integrated initial teacher training programs of the Flemish system. Faculties of education in the Turkish system are not autonomous in relation to developing their own curricula, which contradicts with the great autonomy provided to teacher training institutions (i.e. colleges of teacher education, universities and adult education centers) in the Flemish system. In the Turkish system, YOK has a central and final autonomy to devise the curricula for teacher training, while cooperation of Ministry of Education and universities are also expected. However, with the updating in pre-service teacher training programs (concurrent model in the bachelor' degree) in the academic year 2006-2007, education faculties were provided with the flexibility and partial autonomy by the right given to them to determine some of the courses to be offered in their curricula. They may do this by designing elective courses that will comprise 25 percent of the whole courses on their curricula (MEB, 2011).

As for the curriculum of Bachelor degree teacher training programs (concurrent model), the Turkish system integrates subject studies, general culture and pedagogical and teaching components throughout the entire training program, which is very similar to the curricula of the integrated teacher training programs of the Flemish system. In contrast to compulsory choice of two subjects (disciplines) the secondary education level teachers in the Flemish system make, the teachers in the Turkish system follow one main discipline area, but based on their own wishes and achievement in their main areas (GPA results), they may conduct minor studies (çiftanadal in the Turkish system). In looking at the teaching practice component of the curricula, the Turkish system and Flemish system seem similar in the sense that both pre-service and in-service teaching practice activities are offered in the systems. Though choosing between pre-service or in-service possibilities are left to preferences of the teacher candidates within the specific teacher training programs in the Flemish system, the Turkish system has a system that makes the two obligatory for teacher candidates. As is also the case with the Flemish system, pre-service teaching practice is performed at the schools but teacher candidates have no employment relationship with these schools. The procedures related to the pre-service teaching practice, that is, the monitoring of the teacher candidates both by their university supervisors and the teacher at the practice school is very similar in the two education systems. Following their successful completion of all courses and the preservice teaching practice, the teacher candidates graduate from the universities, and they apply to KPSS to work at the schools of the Ministry of National Education. Once they are appointed passing all KPSS procedures, they spend one-year (at least) or two-year (at most) candidateshipinternship (adayllk-stajyerlik) period during which they have to take some training in relation to the Turkish education system and regulations and also some pedagogic studies. Moreover, they at the same time teach at the schools they are appointed, which is similar to the possibility of in-service teaching practice (i.e. LIO position) in the Flemish system. However, unlike the Flemish system, it is an obligatory process in the Turkish system, not an optional one.

\section{Results regarding the Admission to Teaching Positions and Entry to the Profession}

The employment of teachers' is highly decentralized. The school boards, municipalities and provinces are in charge of recruitment, selection and appointment of teaching staff. Ministry of Education, on the other hand, is responsible for the determination of salary scales and working conditions. At that point, a collective bargaining process is exerted between the teacher unions and the Flemish Ministry of Education. The trade unions are the active participants of the teacher labor market. There are four main teacher unions. There are two Christian unions which are COV (Catholic primary education) and COC (Catholic secondary education), and one ACOD (socialist) 
and one VSOA (liberal). The government and teacher unions perform negotiations on such issues as working conditions and careers of teaching and administrative staff, which is in fact an important characteristic of Flemish education system, and this cooperation with the teacher unions is effective in forming desirable directions and in the implementation of innovations (OECD, 2004).

In contrast to the decentralized teacher employment system in Flanders, Turkey has a centralized teacher employment system in that all teachers (permanent or contractual) are recruited by the Turkish Ministry of National Education (MEB) through an electronic application system. Teacher vacancies and total number of placements are determined by the MEB, and the candidates apply via electronic forms with their KPSS exam scores and school preferences from the school list MEB offers all around Turkey. In this regard, local or school bodies have no function in the recruitment of the teachers as they have in the Flemish system. The teacher unions are not active participants of the teacher labor market in Turkey as they are in the Flemish system.

For the entry of the teachers to the profession in Flanders, there are general conditions of admission (determined by Decrees of 27 March 1991) such as European Union citizenship and compliance with the official teaching language. Apart from these general conditions, there is a linguistic requirement of attainment of level C1 from the European Reference Framework for languages (when positions are not filled, B2 may be accepted). Another necessity is holding skills' certificates corresponding to three types of qualifications, required skills, acceptable skills and other skills certificates. Teachers with a required skills certificate are those having a degree in teacher education in the subject areas and levels that they are going to teach. Acceptable skills certificates are given to those teachers who hold a degree in education, but this degree is not in the subject area or level of the specific teaching position. As is clear from the requirements, a certificate of teaching competence (degree in education) is a must for both required and acceptable skills certificates. Schools and related bodies have the autonomy to select among the teacher candidates holding required and acceptable skills certificates as a rule. However, when there are no available teachers holding the two main certificates, they may deviate from this rule by recruiting individuals with other skills certificates who have a basic degree and/or relevant experience. The salaries of the other skills certificated teachers are lower than the required and accepted skills certificated teachers, and they work via temporary appointment. To upgrade their qualification, they may attend specific teacher training programs (Eurypedia, 2012; OECD, 2002). From above account, it appears that the due to the shortage of teachers, it is possible to work as a teacher without holding a teaching certificate. Though the government has launched and identified two types of teacher training programs since 2007 one of which especially designed for those from other degrees and fields of studies, in case of a teacher deficit with teaching certificates (required and accepted skills certificates), the school bodies and institutions may opt for uncertified teachers, which leads one to question the teacher quality issues.

For the entry of the teachers to the profession in Turkey, like in the Flemish system, there are general conditions (determined with Article 48 of the Civil Servants Law No 657) such as citizenship of the Turkish Republic, age (being older than 18) and a university degree. Other than these general conditions, there are such specific conditions as being in good health for service (to be certified by a health report), holding a Bachelor's degree in the teacher training programs approved by Higher Education Council (Yükseköğretim Kurulu-YÖK), an age limit of 40 to start service for the first time and most importantly a base point or above scored in the Examination of Civil Servant Selection (Kamu Personeli SeçmeSınavi-KPSS; Eurypedia, 2011). The most striking difference between the Turkish and the Flemish systems appear to be the existence of a teacher selection exam. As opposed to the direct applications of those with teaching certificates to the schools in the Flemish system, candidates are required to first take the KPSS exam and the required base point and inevitably an above point to be placed into a their best choices in the electronic form. In this regard, application into a teaching position in Turkey seems more competitive. Another difference is the need for teachers, that is, there is no teacher shortage in Turkey as there 
Mutlu, G. (2016). A comparative look at the teacher training systems: Belgium - Flemish Community and Turkey. Journal of Human Sciences, 13(2), 3320-3337. doi:10.14687/jhs.v13i2.3809

appears there is in Flanders. One can even say that there is redundancy of teachers with teachers with degrees in teacher education waiting for years to be appointed.

\section{Results regarding the Teachers' Legal Status and Image in the Public}

In their study conducted to investigate public perceptions of teacher status in Flanders, Verhovan, Buvens, Aelterman and Rots (2005) found inconsistent results about the public image of teacher status with regard to such aspects of salary (low), social utility (high), knowledge level (low) and responsibility of the teachers (unclear). Their results on the salary aspect show, however, consistent findings with the earlier studies (Hoyle, 2001; OECD, 2004) in that salaries of teachers are considered lower than such occupations of medicine and law that are accorded higher status in the society (Depaepe\& Simon, 1997, as cited in Verhovan et. al). Hoyle (2001); however, contends that the salaries are lower when compared to some other occupations, but other benefits of the job, such as vacations and generous pensions makes it a competitive one. When compared to the OECD countries, on the other hand, salaries of teachers seem relatively high, especially the salaries of the secondary level teachers (OECD, 2004). Nevertheless, more recent Eurypedia website (2011) implies better salary and teacher appraisal conditions today in Flanders.

In talking about the public image of teachers in the Turkish context, one cannot say that it is a well-respected occupation in today's Turkey although, in the past, teachers were respected much more in the society. For the salaries of the teachers, they are lower than the teachers in Flanders talking in OECD (2004) statistics. Given the conditions and context of Turkey, teaching is a not a well-paid job as such professions of law and medicine, which seems similar to the case in Flanders. However, high job security and permanence, long vacations make it a competitive and guaranteed occupation for the graduates of education faculties.

Teachers are not considered civil servants but they have a specific personnel status which differ from the normal status of other public staff because of the specific needs and nature of field of education that also shows variations in relation to their teaching in community education (for the Flemish community) or in subsidized education. However, the differences between the two statuses are being diminished. At the higher education level, again there is a difference between the university college personnel and university personnel, but again there have been some efforts to compose a unified personnel status for both institutions (Eurpedia, 2012; Eurydice, 2009).

Unlike the Flemish case, both the teachers and academic staff at universities are considered civil servants (public officers), and there is a legislation for this (i.e. Civil Servants Law No. 657). However, those working for private schools are considered as employees of the school business they work; but, for some general rules and conditions they follow the same legislation. Though there are some differences between the teachers working for state schools and those for the private sector schools especially for the social security schemes (Emekli Sandığ1 and SSK difference) and salary issues, the differences are being phased out, and efforts continue in Turkey as well to form a unified system of social security.

It appears that there is teacher shortage in Flanders, which may be understood firstly from the re-recruitment of retired teachers (pensioners), and permission given to those over 65 years old to continue teaching. According to an OECD source (2002), a shortage of 1.722 teachers (5.7 percent) would be observed between the years 2000-2004 at the primary education level, and to compensate for the vacancies, nursery teachers would be recruited as primary school teachers. The representatives of the school boards and the unions attribute this shortage to such reasons as the "economic boom since 1994, low status of the teaching profession and the increased complexity of the teaching profession" (OECD, 2002, p. 9).

\section{Results regarding the Conditions of Service and Salaries of Teachers Working in Early Childhood (Nursery) and School Education}

The Flemish community as the financier for both community education and subsidized education pay the salaries of teachers at these education institutions on a monthly basis. The salaries depend on such factors as type of the office held (recruitment or selection etc.), the status 
(temporary or permanent appointment), the earlier performance in the profession (seniority), the number of teaching periods, personal and family situation and other allowances (e.g. childcare). In addition to actual salaries, teachers may be provided with such extra allowances as holiday pay, endof-year-bonus, travel expenses, child allowance, maternity allowance, pre- and after school childcare (i.e. they have a special salary status). However, they can make no choices for the number of teaching periods they can teach, and there is a minimum and maximum number of teaching periods for teachers of different levels. Similarly, in the Turkish system, the government pays the salaries of the teachers working for MEB schools on a monthly basic. Private schools pay for their employee teachers themselves, which contrast with the Flemish government's paying for the subsidized education as well. The criteria that the salaries depend on are more or less similar in the two systems; but, Turkish teachers are deprived of such allowances as holiday pay, end-of-year-bonus, travel expenses, pre- and after school childcare provided to the teachers in Flanders.

In talking about the transfer of teachers, though teachers of temporary appointment may change places on a yearly basis, transfers of permanently appointed staff between schools is very rare (Eurypedia, 2012). The case is somewhat similar in Turkey. It is rare for teachers with high seniority to change places. However, as being public servants, teachers may be asked to change places; however, health and family conditions can be taken into consideration in these transfers (MEB, 2011; Eurydice, 2009).

According to the evaluation framework, teacher of a permanent or temporary appointment could be dismissed from the profession when he or she receives two final markings of insufficient in the two subsequent evaluations or three final markings of insufficient in the course of his or her teaching career, and also due to a mischief and a very serious crime (Eurypedia, 2012). No evaluation scheme like this applies to Turkish teachers. Similar to the Flemish dismissal procedures, on the other hand, the teachers could only be dismissed because of a very serious misconduct or disciplinary behavior determined by legal authorities (MEB, 2011).

Though there is a distinction between those appointed before and after 31 December 1960, the retirement age for those appointed after this date is 60 . The amount of pension to be received is calculated based upon the number or service years and the average salary of the last five years (Eurypedia, 2012). Likewise, the retirement age is 58 for female teachers and 60 for males according to the latest legislation, and the amount of pension is determined based on the number of service years as a teacher in Turkey (MEB, 2011).

\section{Results regarding the Continuing Professional Development (In-service training) for Teachers Working in Early Childhood and School Education}

Schools are required to write an in-service training plan based upon their in-service training needs. Once this plan is approved, they may contact an in-service training agency of their choice and they spend money from their budget for in-service training practices. There are also other in-service training opportunities offered free of charge by the Flemish government and pedagogical counseling services. Teachers of secondary education level may also take in-company work experience placement of at least five days offered in a company, care or welfare institution again within the framework of an in-service plan. Within this framework, there is also entrepreneurship education opportunity (for February 2011 - January 2013 time period) for teachers and lecturers by means of a PROLERON-bis project (a European project for the professional development of teachers in conjunction with entrepreneurship). There is also an online in-service training database that the schools may consult on which different institutions advertise for their in-service training projects. With regard to incentives offered for participation in continuing professional development activities, both the management and staff members of school can ask for in-service training funding as soon as it is apparent that the type in-service training is professionally beneficial and the finding may cover costs of transportation and registration fees. Teachers might even be exempt from their teaching duties when they attend in-service training. 
Unlike the decentralized in-service teacher training activities in Flanders, Turkish education system has mainly a centralized in-service system for teachers. As opposed to the school's own regulations and decision-making power in in-service training issues in the Flemish system, there is Turkish Directorate for In-service Training Office (Hizmetiçi Eğitim Daire Başkanlığı in Turkish) which regulates in-service teacher training activities the country-wide, and the governorships at local levels execute the in-service training activities (Eurydice, 2011). In the Flemish system, the in-service training opportunities are more varied when compared to the sole source of in-service training, MEB in the Turkish system. In talking about the incentives offered for participation in continuing professional development activities, the teachers have no funding opportunities for the self-motivated in-service training activities they wish to attend in contrast to such opportunities offered to the teachers in the Flemish system. However, they may ask for an official permission (with a proof of the date and benefit of the activity) not to perform their teaching duties on the day of any in-service training or seminar activity they themselves plan to attend.

\section{Results regarding the Stages in the Teaching Career and Career Ladders}

The career of a primary school and secondary-school teacher is composed of three key stages: a) temporary appointment with a fixed duration, b) temporary appointment with an unlimited (continuous) duration and lastly c) permanent appointment. Following a minimum of three school years, the temporary member moves onto the second stage of again temporary appointment, but for a continuous duration. After this second step, meeting several other conditions (subvention conditions, days of service etc.), the temporary member is appointed to the permanent position to what the Flemish system names as a recruitment office (i.e. as a teacher), to a selection office (i.e. as a vice-principal) or to a promotion office (i.e. as a school head). For the selection and promotion office conditions, no other additional conditions (years of service etc.) are required (Eurypedia, 2012).

There is somehow a similar procedure in terms of appointment procedures in the two systems. Turkish system being composed of two-stages, candidacy - internship period and the follow-up permanent appointment period differs from the Flemish system which is composed of three key stages in that teachers in the Flemish system appears to have no job security until they are appointed on a permanent basis. Teachers in the Turkish system, on the other hand, will probably pass the candidacy-internship period and thus have the job security from the very beginning of their appointment.

In talking about the career ladders, there is again a similarity between the two systems in relation to being promoted to the principal positions. In the Turkish system, however, there is a recent development called career stages as of 2004. According to the relevant legislation, following the candidacy-internship period, teachers proceed through three main career stages categorized as teacher, master teacher and head teacher stages. Transition to an upper career stage may depend on both experience and educational development of the teachers (graduate studies of the teachers). As the teachers move to a higher career stage, their salaries increase.

\section{Results regarding the Supporting Measures for Teachers and Teacher Education}

There are pedagogical counseling services offered to the teaching staff throughout their professional life (Eurypedia, 2012). In the Turkish context, there are no obvious supportive services for teachers to consult about their professional concerns apart from their contacts with their colleagues and principals.

\section{Results regarding the Evaluation and Accreditation of Teacher Training Programs}

Following the Flemish quality assurance system framework used for higher education institutions, the subsequent stages of internal evaluation, external evaluation and accreditation are followed, and such procedures of site visits, analysis of a written plan, the self-evaluation report of 
the institution and other background documents are employed for evaluation purposes (Eurydice, 2006). The internal self-evaluation is performed, and a self-evaluation form is prepared. Based on the evaluation reported in the self-evaluation report, an external evaluation is performed by an assessment panel of experts (coordinated by VLUHR, the Flemish Universities and University Colleges Council). Based on the evaluation reports and evaluation of the panel, the final quality of the teacher training program is confirmed through accreditation procedures by the Accreditation Organization of the Netherlands and Flanders (NVAO) that decides whether the teacher training program meets minimum international quality standards. The accreditation stage could be performed by any other accreditation organization than NVAO that is listed in European Quality Assurance Register (EQAR) and/or that acts in line with the European Standards for the External Quality Assurance Agencies of Higher Education (Eurypedia, 2012; Eurydice, 2011).

Accreditation of teacher education programs in Turkey is not that active as in Flanders. That is, though YOK has started accreditation studies in 1998 and conducted pilot studies between the years 1998-2002, these studies have been decelerated in the last years. Some national meetings (last held at Ankara University in March 2007) have been conducted to enliven the teacher education program accreditation and standards (MEB, 2011). At YOK, there is a national body responsible for external quality assurance called the Turkish National Agency of Higher Education, and this body works independently of the government and the higher education institutions themselves.

\section{Results regarding the Evaluation of Teachers}

The Flemish government launched a new law on teacher evaluation policy starting with the year 2007 which requires the schools evaluate their all teachers in every four years. As a first step, two evaluators are assigned for each teacher, and these two evaluators are in practice the teacher's principal or assistant principal, and the first evaluator is responsible for performing the major evaluation while the second one for just monitoring the process. After the appointment of the evaluators for the teacher, an individualized document is prepared for the teacher that has the duties and tasks of the teacher and the expected behaviors and acts from the teacher to achieve these duties. Using this job description document as the basis, the principal conducts performance assessment and prepares an evaluation report with a final remark of sufficient and insufficient (Tuytens \& Devos 2010). In looking at this teacher evaluation policy system, it is evident that the principals have too much responsibility. Tuytens and Devos (2010) further put forth that the system offers broad rules for teacher evaluation for the schools, and it offers no elaborated evaluation instruments to employ, which, in turn, brings about great responsibility to the schools and their leaders.

In talking about the Turkish system, evaluation is the responsibility of the Ministry of National Education. MEB execute this responsibility internally and externally. Somewhat an internal evaluation is conducted by the school principals in that they are responsible for teachers' continuous development and identifying and dealing with shortcomings. However, the role and responsibilities of the principals is not at the heart of the evaluation studies, and they have no big responsibilities as the principals in the Flemish system (MEB, 2011). With regard to external evaluations, they are performed at the national level through education supervisors (locally through Head Offices of Education Supervisors -Eğitim Denetmenleri Başkanlıkları - and centrally through the Head Office of Guidance and Supervision - Rehberlik ve Denetim Başkanllğı). 
Mutlu, G. (2016). A comparative look at the teacher training systems: Belgium - Flemish Community and Turkey. Journal of Human Sciences, 13(2), 3320-3337. doi:10.14687/jhs.v13i2.3809

\section{Results regarding the Positions of Academic Staff (Higher Education Teachers)}

Academic staff at universities is grouped into two main clusters, autonomous academic staff and assistant academic staff (Table 1).

Table 1

Academic Staff at Flemish Universities

\begin{tabular}{lll}
\hline Autonomous academic staff (ZAP) & Docent (Lecturer) & \\
& Hoofddocent (Senior lecturer) & \\
& Hoogleraar (Professor) & \\
& Gewoonhoogleraar (Professor ordinarius) \\
& Buitengewoonhoogleraar (Professor \\
& extraordinarius) \\
\hline Assistant academic staff (AAP) & Assistent (Assistant) \\
& Doctor-assistent (Doctor-assistant) \\
& Praktijkassistent of Lector (Practical \\
& assistant or junior practical lecturer) \\
\hline
\end{tabular}

(*Eurypedia, 2012. Retrieved from

https://webgate.ec.europa.eu/fpfis/mwikis/eurydice/index.php/Belgium-Flemish-

Community:Conditions_of_Service_for_Academic_Staff_Working_in_Higher_Education)

In talking about the formal requirements to enter to the profession, a Bachelor's degree will be asked for the for the junior practical lecturer and senior practical lecturer positions, while a Master's degree will be required for lecturer, senior lecturer, assistant and senior research assistants. To work at the autonomous academic staff positions and doctor-assistant position, on the other hand, one is required to hold a doctorate degree, and autonomous academic staff positions are offered through permanent appointment when compared to temporary appointment of those at assistant academic level category. Academic staff is recruited via a public vacancy system which makes it necessary that the vacant position is to be announced by means of at least two public information channels, and they are paid by the universities.

The categorization of the academic staff at the universities into two maim groups (autonomous and assistant academic staff positions) in the Flemish system is very similar to the one in the Turkish system in that at Turkish universities, there are basic teaching staff (ögrretim elemanları in Turkish) who hold no doctorate degrees including lecturers, instructors, experts, research assistants and education planners, and also advanced teaching staff (ögretim üyeleri in Turkish) who have doctorate degrees including assistant professors, associate professors and professors. As is the case with the autonomous academic staff positions in the Flemish system, the associate professors and professor members of the advanced teaching staff are appointed on a permanent basis to the university (i.e. full time permanent status). The Turkish universities recruit academic staff based on a vacancy system announced on the YOK website and some other media channels, which is also similar to the one in the Flemish system. However, unlike the Flemish universities that pay their staff themselves, the academic staff in Turkey is paid centrally by the government.

\section{Conclusion}

The above account presented the results between the two teacher training systems in a comparative manner and clarified the practices performed in both countries. As is clearly seen, there are more differences than similarities. However, some differences were observed as real 
Mutlu, G. (2016). A comparative look at the teacher training systems: Belgium - Flemish Community and Turkey. Journal of Human Sciences, 13(2), 3320-3337. doi:10.14687/jhs.v13i2.3809

development points on behalf of the Flemish teacher education system. What follows are the summaries of these key points:

- There is a strong teacher union tradition in the Flemish teacher training system which enables teachers to have better rights, working and life conditions compared to their Turkish colleagues. Strong teacher unions and such cooperation among teachers bring about more opportunities and advantages for the teachers.

- It is seen that teacher education programs are more autonomous in their curriculum designs when compared to those in Turkey. These programs may have more autonomy in that they may offer teacher training courses based on the specific needs of their own students and their own working contexts. That is, they may offer courses based on the needs-assessment results in their own contexts, which is also a very important first step in curriculum design.

- Flemish quality assurance system for higher education institutions requires accreditation practices to be fulfilled by the teacher training programs so as to increase the quality of teacher training programs. However, such practices have been incomplete with no effective results in Turkey. That is, there is a need for more sustainable practices to develop the quality of teacher training programs in Turkey.

- It is also striking that Flemish teachers receive extra allowances, bonuses and pays during the year. It is believed that these economic opportunities may make the Flemish teachers more comfortable, relaxed and motivated in their job practices. However, teachers working in Turkey have no such extra pays excluding their regular salaries or school extra duty pays.

- There is a different and stricter evaluation system for Flemish teachers which in turn may bring about more teacher quality. Teachers knowing that they are being monitored may pay more attention to their professional life and teaching in the classrooms.

- For the professional development opportunities, it is seen that the Flemish teacher training system outperforms its Turkish counterpart in that there is a strong and well-working in-service training system in Flanders. There are also in-service training funding opportunities for Flemish teachers. Upon the determination of a specific training need, Flemish teachers may ask for free inservice training facilities. Moreover, there are pedagogical counseling services at Flemish schools that may serve the pedagogical needs of the teachers. These services only serve the teachers and their problems and needs.

- In talking about the pre-service teaching system, Turkish education system suffers from several shortcomings. One of these refers to the discrepancy between teacher training received at the university and what teachers face on the job at the real contexts of schools (Çakıroğlu \& Çakıroğlu, 2003). Another shortcoming is related to the lack of communication and cooperation between university teacher educators and teachers working at the Turkish state schools (Şimşek \& Yildırım, 2001).

\section{Recommendations}

The following presents several recommendations in line with the above account. In other words, the following recommendations were derived based on the above concluding statements about the comparison of the two teacher training systems.

- There should be more say and dominance of Turkish teacher unions so as to provide the teachers with European standards and conditions.

- Needs assessment should be a part of teacher training curriculum design process. Based on the results from the needs assessment, teacher training institutions may offer elective courses, which in turn answer the real needs of the students.

- Teacher training programs should be involved in accreditation practices in the Turkish teacher education system. Such practices provides more quality and standardization with regard to 
Mutlu, G. (2016). A comparative look at the teacher training systems: Belgium - Flemish Community and Turkey. Journal of Human Sciences, 13(2), 3320-3337. doi:10.14687/jhs.v13i2.3809

the several components of the teacher training curricula, which in turn will add to the quality of teacher training

- Some economic opportunities or bonuses may be used as reinforcements for the teachers' professionalism.

- Teacher evaluation system should be reorganized in the Turkish teacher education system with a transparent criteria and clearly defined rules.

- In-service training system should be changed in the way that it should meet the real needs of the teachers. The system should find a way to encourage Turkish teachers to take part in such professional development facilities voluntarily and teachers should be financed for such activities.

- There is also need to reconsider the pre-service training system together and in line with the in-service training system. In this regard, practicum sessions should be designed in the way that they should well prepare the candidate teachers for the real contexts and conditions of teaching at the schools.

\section{References}

Comace (2012).General policy for cultural education within teacher training. Retrieved from http://www.comace.org/belgium-flanders/formal-education/teacher-training/general

Çakıroğlu, E. \& Çakıroğlu, J. (2003). Reflections on teacher education in Turkey, European Journal of Teacher Education, 26(2), 253-264. DOI: 10.1080/0261976032000088774

Eurydice. (2006). Quality Assurance in Teacher Education in Europe. Retrieved from http://www.see-educoop.net/education_in/pdf/workshop/tesee/dokumenti/qaen.pdf

Eurydice. (2009). Structures of Education and Training Systems in Europe.Retrieved from http://eacea.ec.europa.eu/education/eurydice/documents/eurybase/structures/041_TR_ EN.pdf

Eurydice. (2011). National system overview on education systems in Europe- Belgium Flemish Community. Retrieved from http://eacea.ec.europa.eu/education/eurydice/documents/eurybase/national_summary_s heets/047_BN_EN.pdf

Eurypedia (European Enclopedia on National Education Systems).(2011). Information on Turkey. Retrieved from https://webgate.ec.europa.eu/fpfis/mwikis/eurydice/index.php/Turkey:Overview

Eurypedia (European Enclopedia on National Education Systems). (2012). Information on Belgium -Flemish Community. Retrieved from https://webgate.ec.europa.eu/fpfis/mwikis/eurydice/index.php/Belgium-FlemishCommunity:Overview

EuroEducation (The European Education Directory). (2016). Belgium (Flemish Community) Higher Education System. Retrieved from http://www.euroeducation.net/prof/belco.htm

Flemish Ministry of Culture and Education. (2008). Education in Flanders: The Flemish educational landscape in a nutshell. Retrieved from http://www.ond.vlaanderen.be/publicaties/eDocs/pdf/120.pdf

Hoyle, E. (2001) Teaching. Prestige, status and esteem, Educational Management \& Administration, 29(2), 139-152.

MEB. (2011). Türk Eğitim Sisteminin Örgütlenmesi. Retrieved from http://sgb.meb.gov.tr/eurydice/kitaplar/Turk_Egitim_sistemi_2011/Turk_Egitim_Sistemi nin_Orgutlenmesi_2011.pdf 
Mutlu, G. (2016). A comparative look at the teacher training systems: Belgium - Flemish Community and Turkey. Journal of Human Sciences, 13(2), 3320-3337. doi:10.14687/jhs.v13i2.3809

OECD. (2002). Attracting, Developing and Retaining Effective Teachers - Thematic Review: Background report for the Flemish Community of Belgium. Retrieved from http://www.oecd.org/dataoecd/32/33/2404904.pdf

OECD. (2004). Attracting, Developing and Retaining Effective Teachers - Country Note: The Flemish Community of Belgium. Retrieved from http://www.oecd.org/dataoecd/32/48/33732207.pdf

OECD. (2010). Learning for Jobs OECD Reviews of Vocational Education and Training: Belgium (Flanders). http://www.oecd-ilibrary.org/education/oecd-reviews-of-vocational-educationand-training-a-learning-for-jobs-review-of-belgium-flanders-2010_9789264113718-en

Şimşek, H. \& Yıldırım, A. (2001). The reform of pre-Service teacher education in Turkey, in: R.G.Sultana (Ed.) Challenge and Change in the Euro-Mediterranean Region (pp. 411-430). New York: Peter Lang.

Tuytens, M. \&Devos, G. (2010). The influence of school leadership on teachers' perception of teacher evaluation policy. Educational Studies, 36(5), 521-536

U.S. Department of State. (2012). Belgium. Retrieved from http://www.state.gov/r/pa/ei/bgn/2874.htm

UNESCO (2007). Belgium (Flemish Community). Retrieved http://www.ibe.unesco.org/fileadmin/user_upload/archive/Countries/WDE/2006/WES TERN_EUROPE/Belgium/Belgium_(Flemish_Community).pdf

Verhoeven, J. C., Aelterman, A. , Rots, I. \&Buvens, I. (2006). Public perceptions of teachers' status in Flanders. Teachers and Teaching: Theory and Practice, 12(4), 479- 500.

\section{Appendix A}

Educational Umbrella Networks

\begin{tabular}{|c|c|c|}
\hline Educational umbrella organisation & Educational network & URL \\
\hline $\begin{array}{l}\text { Flemish Secretariat of Catholic Education (Vlaams } \\
\text { Secretariaat van het Katholiek Onderwijs - VSKO) }\end{array}$ & Catholic education & http://ond vsko be \\
\hline $\begin{array}{l}\text { Education Secretariat of Cities and Municipalities of the } \\
\text { Flemish Community (Onderwijssecretariaat van de } \\
\text { Steden en Gemeenten van de Vlaamse Gemeenschap } \\
\text { (OVSG)) }\end{array}$ & City and municipal education & hittp://www.ovsg. be \\
\hline $\begin{array}{l}\text { Provincial Education Flanders (Provinciaal Onderwijs } \\
\text { Vlaanderen - POV) }\end{array}$ & Provincial education & http://www pov be \\
\hline $\begin{array}{l}\text { The Board of GO!. } \\
\text { This Board does not only represent GO! but also acts as } \\
\text { the central organising body for GO! }\end{array}$ & $\begin{array}{l}\text { GO! Education of the Flemish } \\
\text { Community }\end{array}$ & http:/Www gemeenschapsonderwils be \\
\hline $\begin{array}{l}\text { Federation of Independent Pluralist Emancipatory } \\
\text { Alternative Schools (Federatie van Onafhankelijke } \\
\text { Pluralistische Emancipatorische Methodescholen - } \\
\text { FOPEM) }\end{array}$ & $\begin{array}{l}\text { Group of } 11 \text { Freinet schools, } \\
\text { experience-oriented schools, } \\
\text { project schools in subsidised } \\
\text { private non-denominational } \\
\text { education }\end{array}$ & http://users.skynet.be/fopem \\
\hline $\begin{array}{l}\text { Federation of Rudolf Steiner schools (Federatie van } \\
\text { Rudolf Steinerscholen) }\end{array}$ & Steiner schools & http://www steinerscholen be \\
\hline $\begin{array}{l}\text { Flemish Schools' Forum (Vlaams Onderwijs } \\
\text { Overlegplatform - VOOP) }\end{array}$ & Non-denominational schools & http://www voop be \\
\hline $\begin{array}{l}\text { Organising bodies of subsidised private } \\
\text { Protestant-Christian Schools (IPCO) }\end{array}$ & $\begin{array}{l}\text { Subsidised private } \\
\text { Protestant-Christian schools }\end{array}$ & http://www.ipco.be \\
\hline $\begin{array}{l}\text { Forum of Small Education providers (Overleg Kleine } \\
\text { Onderwijsverstrekkers - OKO) }\end{array}$ & $\begin{array}{l}\text { Consultation platform of FOPEM, } \\
\text { VOOP, Federation of Steiner } \\
\text { schools, IPCO }\end{array}$ & http://www. oko.bel \\
\hline
\end{tabular}

(Source: Eurypedia, 2012, from

https://webgate.ec.europa.eu/fpfis/mwikis/eurydice/index.php/Belgium-FlemishCommunity:Administration_and_Governance_at_Local_and/or_Institutional_Level) 
Mutlu, G. (2016). A comparative look at the teacher training systems: Belgium - Flemish Community and Turkey. Journal of Human Sciences, 13(2), 3320-3337. doi:10.14687/jhs.v13i2.3809

\section{Appendix B}

Phases of Schooling in Flanders

\begin{tabular}{|l|l|}
\hline Primary education - Lager Onderwijs & From 6 to 12 years of age \\
\hline Secondary education - Secundair onderwijs & From 12 to 18 years of age \\
\hline $\begin{array}{l}\text { 1st stage: 1st grade A - 1st grade B (for pupils who did not obtain a } \\
\text { getuigschrift basisonderwijs - (certificate of elementary education) } \\
\text { 2nd grade - 2nd Beroepswoorbereidend leerjaar (pre-vocational year) }\end{array}$ & From 12 to 14 years of age \\
\hline $\begin{array}{l}\text { 2nd stage offering four branches of education: general - technical - } \\
\text { arts - vocational secondary education (algemeen - technisch - kunst } \\
\text { - beroepssecundair onderwijs) }\end{array}$ & From 14 to 16 years of age \\
\hline $\begin{array}{l}\text { 3rd stage: general - technical - arts - vocational secondary education } \\
\text { or part-time vocational secondary education (algemeen - technisch - } \\
\text { kunst - beroepssecundair onderwijs of deeltijds beroepssecundair } \\
\text { onderwijs) }\end{array}$ & From 16 to 18 years of age \\
\hline
\end{tabular}

(Source: Eurydice, 2011. Retrieved from

http://eacea.ec.europa.eu/education/eurydice/documents/eurybase/national_summary_sheets/04 7_BN_EN.pdf) 